\title{
COMPARISON OF FIVE NEW SWEET CHERRY CULTIVARS BRED IN ROMANIA, WITH THEIR PARENTAL FORMS
}

\author{
Margareta CORNEANU, Elena IUREA*, Sorina SIRBU \\ Fruit Growing Research Station (FGRS) Iaşi, Romania
}

Received: October 2020; Accepted: March 2021

\begin{abstract}
The studies were performed for four consecutive years (2016-2019) at the Fruit Growing Research Station (North-East part of Romania), using eleven sweet cherry genotypes as research material. Five of them are new cherry cultivars - 'Cătălina', 'Andreiaş', 'Maria', 'George', and 'Margonia' - obtained by means of controlled hybridization or open pollination, and six of them are their progenitors ('Van', 'Boambe de Cotnari', 'Stella', 'Fromm', 'Ciliegia di Ottobre', and the 'HC 27/4' hybrid). The experiment compared the traits of new cultivars with those of their progenitors. The following traits were evaluated: tree vigor, frost damage, the phenological stages, and the physical and chemical traits of the fruit. The highest values concerning the fruit's weight have been recorded for 'Andreiaş' ( $10.0 \mathrm{~g})$ and 'Maria' ( $7.6 \mathrm{~g}$ ), the content of soluble substance was between 16.6 and $19.5^{\circ}$ Brix, the titratable acidity was between 0.413 and $0.675 \mathrm{mg}$ malic acid $100 \mathrm{~mL}^{-1}$ juice, and the total content of polyphenols was recorded with values between 268.00 and $488.75 \mathrm{mg} \mathrm{GAE} \cdot 100 \mathrm{~mL}^{-1}$ of fresh juice. The new cultivars have mostly superior traits, especially frost damages, productivity, fruit quality, and fruit's cracking percentage compared with their parental genotypes.
\end{abstract}

Key words: sweet cherry, Prunus avium, frost resistance, fruit cracking, fruit quality, tree vigor

\section{INTRODUCTION}

Romania is a country that has a tradition in the growing of sweet cherries (Prunus avium L.), which is favored by climatic conditions (Budan \& Grădinariu 2000). The fruit is desired and appreciated by consumers as the first fruit to be eaten in spring ( $\mathrm{Ga}-$ nopoulos et al. 2018; Maglakelidze et al. 2017; Quero-García et al. 2017). The deliberate breeding of cherry cultivars has been performed in Romania for over 50 years, under well-defined programs. Therefore, a rich germplasm collection of genotypes both local and foreign was created for breeding purposes. The following are main objectives of the cherry breeding goals: obtaining of cultivars with early yielding, productive, self-compatible, low vigor of trees and crown compactness, resistant to anthracnose and monilia, frost, and fruit cracking, late blooming, superior quality of the fruit, and wide range of ripening terms to extend the cherry yielding season (Sansavini \& Lugli 2008; Milatović 2011; Schuster et al. 2014). To obtain new cherry cultivars, it is recommended to know the progenitors, the traits to be improved, and the mode of their transmission to offspring (Branişte et al. 2007; Höfer \& Giovannini 2017). Following this activity at Fruit Growing Research Station Iaşi, during 1981-2018, 28 new sweet cherry cultivars were obtained through controlled hybridization, open pollination, and clonal selection. All these cultivars were approved and patented during 1999-2018, but only one cultivar - 'Maria' - is self-fertile.

The aim of the research was to characterize new sweet cherry cultivars that are superior to their parental forms $(q \times \overbrace{}^{\Uparrow})$, obtained at the Fruit Growing Research Station Iaşi, Romania, increasing the domestic assortments and beyond. 


\section{MATERIALS AND METHODS}

The studies were conducted over four consecutive years (2016-2019) at the Fruit Growing Research Station Iaşi. The studied biological material consists of five new cherry genotypes: 'Cătălina', 'Andreiaş', 'Maria', 'George' (obtained through controlled hybridization), and 'Margonia' (obtained through open pollination), and six their progenitors: 'Van', 'Boambe de Cotnari', 'Stella', 'Fromm', 'Ciliegia di Ottobre', and the 'HC 27/4' hybrid (Table 1). All the genotypes were grafted on Prunus mahaleb L. seedlings as rootstock and planted at $5 \times 4 \mathrm{~m}$ distances in the spring of 2000 in the experimental plot. The experimental setup is linear; nine trees ( 3 replications $\times 3$ trees) per cultivar were evaluated for 4 years. The trees were trained as free palmette system, without support or irrigation. In the rows of the trees, the soil was cultivated with a rotary cultivator, and between the rows, the grass was mowed several times during the season. The control of diseases and pests was typical for the Prunus avium L. cultivars.

Among the eleven studied genotypes, one genotype belongs to early maturing ('Cătălina'), seven genotypes belong to medium-season maturing ('Andreiaş', 'Maria', 'Van', 'Boambe de Cotnari', 'Stella', 'Fromm', and 'HC 27/4'), and three genotypes belong to late ripening ('Margonia', 'George', and 'Ciliegia di Ottobre').

The weather conditions (temperature and precipitations) have been recorded by the meteorological station, located in the experimental fields. The Iaşi area is characterized by the average multiannual temperature of $10.5^{\circ} \mathrm{C}$ and $562.6 \mathrm{~mm}$ of the multiannual sum of precipitations. During the 4 years of study, the average temperature was $11.5^{\circ} \mathrm{C}$, with the absolute maximum of $37.7^{\circ} \mathrm{C}$ (2017), the absolute minimum of $-21.9^{\circ} \mathrm{C}(2017)$, and the total amount of precipitations were in excess in $2016(690.8 \mathrm{~mm})$ and $2017(1045.8 \mathrm{~mm})$ and in deficit in 2018 $(530.6 \mathrm{~mm})$ and $2019(451.0 \mathrm{~mm})$. The estimation of resistance to frost during the complete cherry bloom phenophase (90-100\% open flowers) was determined based on the rate of the gynoecium harm (ovary, style, and stigma) of each third part of the tree crown from one hundred flowers for each cultivar.
For the estimation of the growing and fructification phenophases, the Fleckinger system was used (1964).

The index of productivity of the cultivars was determined from fruit set under the open pollination. Highly productive cultivars are considered to have an index of productivity (percentage of resulted fruits, determined 25-30 days after petals fall) with minimum values of 30-35\% (Cociu \& Oprea 1989).

Specific Prunus avium L. descriptors were used for the fruits assessment in accordance with the UPOV TG/35/7, 2006 questionnaire. The evaluated fruits have been harvested per each cultivar and repetitions in full maturation stage. The average weight of the fruit and stone (g) was measured by weighting 30 fruits and 30 stones individually per repetition with the electronic scale of sensitivity $0.01 \mathrm{~g}$ and then calculating the average on the obtained data. The equatorial diameter (D) of the fruit ( $\mathrm{mm}$ ) was determined with the digital calipers for 30 fruits from three repetitions. The pulp firmness, the pulp adherence to stone, and the taste of the fruit were rated on a scale of 1-9 (UPOV). The content in soluble dry substance was determined using the manual refractometer Zeiss (in degrees Brix). The titratable acidity of fruit was determined using the potentiometric method (Ghimicescu 1977), and the total content of polyphenols was determined using the Folin-Ciocalteu method (Jayaprakasha et al. 2001). The resistance of fruit to cracking was determined using the Christensen method, counting the cracked fruits after immersion in distilled water at $20{ }^{\circ} \mathrm{C}$ for 6 hours (Webster \& Looney 1996).

The experimental data were statistically interpreted using ANOVA and the multiple comparisons method with the Duncan test, with $\mathrm{p}=0.05$.

\section{RESULTS AND DISCUSSION}

The bloom phenophase took place between 2nd and 28th of April. Bloom duration was from 8 to 11 days when the sweet cherry cultivars pollinated each other (Table 2). In 2016 and 2017, the bloom was triggered beginning earlier by $2-10$ days in comparison with 2018 and 2019. It was noticed that 'Margonia', and 'Ciliegia di Ottobre' bloomed 1 week later than the other cultivars (Table 2). 
The lateness of bloom in cherry is an extremely important trait to avoid losses caused by late spring frosts and hoar frosts. From the other site, the weather conditions had an important effect on the flowering period and then on the setting of fruits in sweet cherry (Głowacka \& Rozpara 2014).

Fruit maturity of 'Cătălina' takes place one month earlier than in the parents, but in 'George' one month later than in the pollinator and two months earlier in comparison with their maternal progenitor. In 'Margonia' fruit maturation was 13 15 days later in comparison with their maternal progenitor 'Van'. 'Maria' and 'Andreiaş' fruit ripened in the similar time to their parents (Table 2). The number of days between end of bloom and maturation was between 35 days for cultivar 'Cătălina' (22-27 days less than the two progenitors) and 85 days for cultivar 'George' ( 28 days later than the paternal progenitor 'Fromm' and 52 days earlier than the maternal progenitor 'Ciliegia di Ottobre').

The flowers' resistance to spring frost is an important trait both economically in fruit production and scientifically for genetic experiments. In our study, in the second decade of April 2017, when the sweet cherries were blooming, the trees were covered with a heavy layer of snow for a period longer than 24 hours and the minimum temperature recorded was $-2.8^{\circ} \mathrm{C}$. Under these conditions, the ovaries that were already fertilized got affected, compromising largely the production of fruits. These results are in concordance with other research concerning the flowers' resistance to spring frost in sweet cherry cultivars (Rodrigo 2000; Long 2013), which show that the ovaries are the most susceptible cherry organ to frost. Hence, the effect of extremely low temperatures on the gynoecium of cherry flowers, under the above conditions, was damaged for $49.0 \%$ lost in cultivar 'George' and $66 \%$ in cultivar 'Cătălina'. Comparing each cultivar with their progenitors, statistically, cultivar 'George' $(49.0 \%)$ and cultivar 'Maria' (54.8\%) were less susceptible for frost damage in comparison with their paternal progenitors. The other three cultivars did not differ in frost damage compared with their parents (Table 3). Our results are in accordance with those of Fotiric Akšić et al. (2013), which showed that climatic conditions affect floral biology and have an influence on differences between genotypes and the yearly variation of fruit production.

In terms of productivity, the new sweet cherry cultivars recorded values of the fruit set percentage from $21 \%$ to $51.4 \%$, and 'Maria', 'Andreiaş', and 'George' set fruits higher than their parents although differences were not significant (Table 2).

The cultivar 'Andreiaş' recorded superior values in the fruit weight and equatorial diameter $(10.0 \mathrm{~g}$ and $25.3 \mathrm{~mm}$, respectively) that were significantly higher in comparison with their progenitors 'Boambe de Cotnari' (7.4 $\mathrm{g}$ and $24.3 \mathrm{~mm}$ ) and 'HC 27/4' (7.1 $\mathrm{g}$ and $23.4 \mathrm{~mm}$ ). The cultivar 'George' fruit was intermediate between parents $(7.3 \mathrm{~g}$ and $23.0 \mathrm{~mm})$. The cultivar 'Maria' did not differ in weight but its equator value surpassed the parental. The weights of cultivars 'Cătălina' (7.5 g and $24.0 \mathrm{~mm}$ ) and 'Margonia' ( $7.4 \mathrm{~g}$ and $24.5 \mathrm{~mm}$ ) recorded similar values as their progenitors (Table 3 ).

The fruit's size (equatorial diameter and fruit's weight) is a genetic trait particular to every cultivar, but it is also under the influence of the growing technology, the quantity of the fruits' production, the pedoclimatic factors, rootstock, and so on. These traits represent an extremely important element in defining the market value (Ruisa 2008). Usually, on a global scale, the consumers prefer a big-sized fruit of cherry, with a high sweet taste and shiny red color (Turner et al. 2008).

The proportion of stone's weight $(\mathrm{g})$ values to the total fruit's weight (\%) in the five sweet cherry cultivars was superior or inferior compared with that in progenitors (Table 3 ). The cultivars 'Andreiaş' and 'George' recorded lower values in comparison with their progenitors. This value in cultivar 'Maria' did not differ compared with that in parents, and the recording values of cultivars 'Cătălina' and 'Margonia' were slightly higher than those of their progenitors 'Van' and 'Boambe de Cotnari' (Table 3). 
The sweet cherry fruit's cracking is a negative phenomenon that can damage under certain conditions up to $90 \%$ of the harvest (Demirsoy \& Demirsoy 2008). Therefore, a selection for this trait is so important in sweet cherry breeding. The rate of damaged fruits in cultivars 'Cătălina' (6.0\%), 'Margonia' (1.3\%), 'Maria' (9.3\%), 'Andreiaş' (5.5\%), and 'George' (5.8\%) displays a superior resistance for cracking in comparison with their progenitors: 'Van', 'Boambe de Cotnari', 'Stella', or 'Fromm' (Table 3).

Table 1. Female ( $(+)$ and male $\left({ }^{\Uparrow}\right)$ progenitors of the new sweet cherry cultivars

\begin{tabular}{|c|c|c|c|c|c|c|}
\hline \multirow{2}{*}{ Cultivar } & \multicolumn{6}{|c|}{ Progenitors $(q \times \overbrace{}^{\lambda})$; cultivar } \\
\hline & 'Van' & 'Boambe de Cotnari' & 'Stella' & 'Ciliegia di Ottobre' & 'HC 27/4' & 'Fromm' \\
\hline 'Cătălina' & q & $0^{\lambda}$ & - & - & - & - \\
\hline 'Margonia' & $q(\mathrm{OP} *)$ & - & - & - & - & - \\
\hline 'Maria' & q & - & 0 & - & - & - \\
\hline 'Andreiaş' & - & q & - & - & ๙ & - \\
\hline 'George' & - & - & - & q & - & $\hat{0}$ \\
\hline
\end{tabular}

* open pollination

Table 2. The evolution of the growing phenophases in sweet cherry cultivars (FGRS Iaşi 2016-2019)

\begin{tabular}{|c|c|c|c|c|c|c|c|}
\hline Genotypes & $\begin{array}{c}\text { Beginning } \\
\text { of bloom } \\
\quad(61)\end{array}$ & $\begin{array}{c}\text { Average } \\
\text { date for } \\
\text { the beginning } \\
\text { of bloom }\end{array}$ & $\begin{array}{l}\text { End } \\
\text { of bloom } \\
(69)\end{array}$ & $\begin{array}{l}\text { Bloom } \\
\text { duration } \\
\text { (days) }\end{array}$ & $\begin{array}{l}\text { Ripening } \\
\text { time } \\
(89)\end{array}$ & $\begin{array}{c}\text { Number } \\
\text { of days between } \\
\text { the end of bloom } \\
\text { and harvesting } \\
\text { maturity }^{1} \\
(\mathrm{n}=5)\end{array}$ & $\begin{array}{l}\text { Natural } \\
\text { fertility }{ }^{1} \\
(\%)\end{array}$ \\
\hline 'Cătălina' & 02-10 IV & $06 \mathrm{IV}$ & 10-19 IV & 10 & $17-28 \mathrm{~V}$ & $35^{\mathrm{f}}$ & $27.9^{b}$ \\
\hline 'Van' & 04-11 IV & $06 \mathrm{IV}$ & 15-18 IV & 10 & 08-15 VI & $62^{\mathrm{d}}$ & $37.8^{\mathrm{b}}$ \\
\hline $\begin{array}{l}\text { 'Boambe } \\
\text { de Cotnari' }\end{array}$ & 04-10 IV & $06 \mathrm{IV}$ & 12-19 IV & 10 & 06-16 VI & $57^{e}$ & $21.0^{\mathrm{b}}$ \\
\hline 'Margonia' & 09-16 IV & $14 \mathrm{IV}$ & 15-28 IV & 10 & $20-29 \mathrm{VI}$ & $65^{\mathrm{c}}$ & $51.4^{\mathrm{a}}$ \\
\hline 'Maria' & 04-09 IV & $06 \mathrm{IV}$ & 11-19 IV & 10 & 06-15 VI & $62^{\mathrm{d}}$ & $47.2^{\mathrm{b}}$ \\
\hline 'Stella' & 04-11 IV & $07 \mathrm{IV}$ & 14-20 IV & 11 & $10-15 \mathrm{VI}$ & $57^{e}$ & $30.4^{b}$ \\
\hline 'Andreiaş' & 04-13 IV & $08 \mathrm{IV}$ & 14-20 IV & 10 & 06-15 VI & $55^{\mathrm{e}}$ & $49.3^{b}$ \\
\hline 'HC 27/4' & 06-11 IV & $07 \mathrm{IV}$ & 11-20 IV & 8 & $05-15 \mathrm{VI}$ & $56^{\mathrm{e}}$ & $34.0^{\mathrm{b}}$ \\
\hline 'George' & 04-14 IV & $09 \mathrm{IV}$ & 14-23 IV & 11 & 07-16 VII & $85^{\mathrm{b}}$ & $41.5^{\mathrm{b}}$ \\
\hline $\begin{array}{l}\text { 'Ciliegia } \\
\text { di Ottobre' }\end{array}$ & 07-14 IV & $10 \mathrm{IV}$ & 15-23 IV & 10 & 01-13 IX & $142^{\mathrm{a}}$ & $40.2^{\mathrm{b}}$ \\
\hline 'Fromm' & 06-12 IV & $08 \mathrm{IV}$ & 13-20 IV & 8 & 08-15 VI & $57^{\mathrm{e}}$ & $41.0^{\mathrm{b}}$ \\
\hline
\end{tabular}

${ }^{1}$ different letters correspond with the significant statistical difference for $\mathrm{P} \leq 5 \%$, Duncan test 
Table 3. Ovary frost damages, fruit and stone size and cracking resistance of new sweet cherry cultivars compared with their progenitors (FGRS Iaşi 2016-2019)

\begin{tabular}{|c|c|c|c|c|c|c|}
\hline $\begin{array}{l}\text { New cultivars } \\
\text { and progenitors }\end{array}$ & $\begin{array}{c}\text { Ovary frost } \\
\text { damages }{ }^{1,2} \\
(\%)\end{array}$ & $\begin{array}{c}\text { Fruit average } \\
\text { weight } \\
\text { (g) }\end{array}$ & $\begin{array}{c}\text { Fruit } \\
\text { equatorial } \\
\text { diameter } \\
(\mathrm{mm})\end{array}$ & $\begin{array}{c}\text { Stone } \\
\text { average } \\
\text { weight } \\
(\mathrm{g})\end{array}$ & $\begin{array}{c}\text { Stone } \\
\text { weight share } \\
\text { in the fruit } \\
(\%)\end{array}$ & $\begin{array}{c}\text { Fruit's } \\
\text { resistance } \\
\text { to cracking } \\
(\%)\end{array}$ \\
\hline 'Cătălina' & $66.0^{\mathrm{a}}$ & $7.5^{\mathrm{a}}$ & $24.0^{\mathrm{c}}$ & $0.31^{\mathrm{b}}$ & $4.13^{\mathrm{b}}$ & $6.0^{c}$ \\
\hline 'Van' $(+)$ & $64.0^{\mathrm{a}}$ & $7.6^{\mathrm{a}}$ & $25.7^{\mathrm{a}}$ & $0.28^{\mathrm{b}}$ & $3.68^{\mathrm{b}}$ & $43.3^{\mathrm{a}}$ \\
\hline $\begin{array}{l}\text { 'Boambe } \\
\text { de Cotnari' }(ふ)\end{array}$ & $64.0^{\mathrm{a}}$ & $7.4^{\mathrm{a}}$ & $24.3^{\mathrm{b}}$ & $0.36^{\mathrm{a}}$ & $4.86^{\mathrm{a}}$ & $21.3^{\mathrm{b}}$ \\
\hline 'Margonia' & $62.0^{\mathrm{a}}$ & $7.4^{\mathrm{a}}$ & $24.5^{\mathrm{a}}$ & $0.35^{\mathrm{a}}$ & $4.73^{\mathrm{a}}$ & $1.3^{\mathrm{b}}$ \\
\hline 'Van' (†OP*) & $64.0^{\mathrm{a}}$ & $7.6^{\mathrm{a}}$ & $24.5^{\mathrm{a}}$ & $0.28^{\mathrm{b}}$ & $3.68^{\mathrm{b}}$ & $43.3^{\mathrm{a}}$ \\
\hline 'Maria' & $54.8^{c}$ & $7.6^{\mathrm{a}}$ & $25.2^{\mathrm{a}}$ & $0.25^{\mathrm{b}}$ & $3.29^{\mathrm{a}}$ & $9.3^{\mathrm{b}}$ \\
\hline 'Van' $(+)$ & $64.0^{\mathrm{a}}$ & $7.6^{\mathrm{a}}$ & $24.5^{\mathrm{b}}$ & $0.28^{\mathrm{a}}$ & $3.68^{\mathrm{a}}$ & $43.3^{\mathrm{a}}$ \\
\hline 'Stella' $\left({ }^{\lambda}\right)$ & $60.8^{\mathrm{b}}$ & $7.5^{\mathrm{a}}$ & $23.4^{\mathrm{c}}$ & $0.30^{\mathrm{a}}$ & $4.00^{\mathrm{a}}$ & $70.3^{\mathrm{a}}$ \\
\hline 'Andreiaş' & $58.3^{\mathrm{a}}$ & $10.0^{\mathrm{a}}$ & $25.3^{\mathrm{a}}$ & $0.33^{\mathrm{b}}$ & $3.30^{\mathrm{c}}$ & $5.5^{\mathrm{b}}$ \\
\hline $\begin{array}{l}\text { 'Boambe } \\
\text { de Cotnari' ( }(+)\end{array}$ & $64.0^{\mathrm{a}}$ & $7.4^{\mathrm{b}}$ & $24.3^{\mathrm{b}}$ & $0.36^{\mathrm{b}}$ & $4.86^{\mathrm{b}}$ & $21.3^{\mathrm{a}}$ \\
\hline 'HC 27/4’ (ふొ) & $61.0^{\mathrm{a}}$ & $7.1^{\mathrm{b}}$ & $23.4^{\mathrm{c}}$ & $0.40^{\mathrm{a}}$ & $5.63^{\mathrm{a}}$ & $2.2^{\mathrm{b}}$ \\
\hline 'George' & $49.0^{\mathrm{b}}$ & $7.3^{\mathrm{b}}$ & $23.0^{\mathrm{b}}$ & $0.33^{c}$ & $4.52^{\mathrm{b}}$ & $5.8^{\mathrm{b}}$ \\
\hline $\begin{array}{l}\text { 'Ciliegia } \\
\text { di Ottobre' }(+) \\
\end{array}$ & $55.0^{\mathrm{b}}$ & $2.6^{\mathrm{c}}$ & $13.5^{\mathrm{c}}$ & $0.45^{\mathrm{a}}$ & $17.31^{\mathrm{a}}$ & $17.3^{\mathrm{a}}$ \\
\hline 'Fromm' (さ) & $63.0^{\mathrm{a}}$ & $8.0^{\mathrm{a}}$ & $25.8^{\mathrm{a}}$ & $0.38^{\mathrm{b}}$ & $4.75^{\mathrm{b}}$ & $10.0^{\mathrm{b}}$ \\
\hline
\end{tabular}

${ }^{1}$ different letters correspond with the significant statistical difference for $\mathrm{P} \leq 5 \%$, Duncan test

${ }^{2}$ statistical differences was calculated between each new cultivar and its progenitors

The epidermis color was yellow ('Margonia'), shiny red ('Maria', 'George'), or dark red ('Cătălina', 'Andreiaş'). For all the cultivars, the fruits were heart-shaped and tasted sweet, without the pulp adherence to stone, with the firm pulp, except for cultivar 'Cătălina' (early maturation) whose pulp firmness was average (Table 4).

Several chemical compounds of the sweet cherry fruit represent a major source of antioxidants (Beceanu 2008; Usenik et al. 2008).

The values of the fruit composition are extremely important because they determine the taste and nutritional value of fruit (Kappel et al. 1996). In our results, SDS values in cultivars 'Maria' (19.5 Brix), 'Andreiaş' (18.7 Brix), 'Cătălina' (18.1 Brix), and 'George' (17.5 Brix) were superior in comparison with those in their progenitors (Table 5).
Transmission of this trait was similar to that in other studies on SDS values in sweet cherry cultivars (Vursavuş et al. 2006; Jänes et al. 2010).

The ratio between the soluble dry substance and the titratable acidity is the parameter that reflects the balance between the sweet and sour taste of the fruit, influencing the quality of the taste (Vangdal 1985; Crisosto et al. 2002). In our study, cultivars 'Maria', 'Andreiaş', and 'George' recorded superior statistical differences in comparison with their progenitors (Table 5). Similar proportions were reported by Fotirić Akšić and Nikolić (2013).

The total content of polyphenols is important for defining the taste and flavor of the cherries and for an antioxidant value (Chaovanalikit \& Wrolstad 2004; Skrzyński et al. 2016; Hallmann \& Rozpara 2017). 
Contents of polyphenols found in the fruit of 'Maria' and 'Catalina' were instantly higher in at least one of their parental genotypes, but in 'Andreiaş' and 'George', the values were much higher than those in mother cultivar and almost the same as in the paternal cultivar. 'Margonia' (314.75 mg GAE·100 mL $\mathrm{m}^{-1}$ ) recorded a value close to its maternal progenitor
'Van' (323.56 mg GAE·100 mL ${ }^{-1}$ ) (Table 5). The five new sweet cherry cultivars have a sweet taste and nice flavor, being extremely attractive for consumers.

The sweet cherry genotypes are strongly heterozygotic, and the newly obtained cultivars have a high possibility to differ in morphological, physiological, and biochemical traits compared with parents.

Table 4. Physical and organoleptic traits of the fruit of the new sweet cherry cultivars (FGRS Iaşi 2016-2019), according to UPOV (2006)

\begin{tabular}{|c|c|c|c|c|c|}
\hline New cultivars & Epidermis color ${ }^{1}$ & Pulp firmness ${ }^{2}$ & Fruit's shape ${ }^{3}$ & Pulp adherence to stone & Taste $^{4}$ \\
\hline 'Cătălina' & 7 & 5 & 1 & non-adherent & 7 \\
\hline 'Margonia' & 1 & 7 & 1 & non-adherent & 5 \\
\hline 'Maria' & 5 & 7 & 1 & non-adherent & 7 \\
\hline 'Andreiaş' & 7 & 7 & 1 & non-adherent & 7 \\
\hline 'George' & 5 & 7 & 1 & non-adherent & 7 \\
\hline
\end{tabular}

${ }^{1}$ a scale of 1-8: 1 - yellow; 2 - yellow with red; 5 - shiny red; 7 - dark red; 8 - black;

2 a scale of 3-9: 3 - soft; 5 - average; 7 - firm; 9 - very firm;

${ }^{3}$ a scale of 1-5: 1 - heart-shaped; 2 - kidney-shaped; 4 - circular;

4 a scale of 3-7: 3 - weak; 5 - average sweet; 7 - very sweet

Table 5. The content of soluble dry substance, titratable acidity, polyphenols and ratio of soluble dry substance to titratable acidity of the fruit of sweet cherry cultivars (FGRS Iaşi 2016-2019)

\begin{tabular}{|c|c|c|c|c|}
\hline Genotypes & $\begin{array}{l}\mathrm{SDS}^{1 *} \\
\left({ }^{\circ} \mathrm{Brix}\right)\end{array}$ & $\begin{array}{c}\text { TA }^{* *} \\
(\mathrm{mg} \text { malic acid per } 100 \mathrm{~mL})\end{array}$ & $\begin{array}{c}\text { SDS : } \mathrm{TA}^{* * *} \\
(\%)\end{array}$ & $\begin{array}{c}\text { Total content } \\
\text { of polyphenols } \\
\text { (mg GAE per } 100 \mathrm{~mL})\end{array}$ \\
\hline 'Cătălina' & $18.1^{\mathrm{c}}$ & $0.880^{\mathrm{a}}$ & $20.568^{f}$ & $420.75^{b}$ \\
\hline 'Van' & $17.2^{\mathrm{c}}$ & $0.680^{\mathrm{b}}$ & $25.220^{\mathrm{e}}$ & $323.56^{\mathrm{d}}$ \\
\hline 'Boambe de Cotnari' & $17.9^{c}$ & $0.705^{\mathrm{b}}$ & $25.390^{\mathrm{e}}$ & $92.25^{\mathrm{f}}$ \\
\hline 'Margonia' & $16.6^{c}$ & $0.675^{b}$ & $24.555^{\mathrm{e}}$ & $314.75^{\mathrm{d}}$ \\
\hline 'Maria' & $19.5^{\mathrm{a} 1}$ & $0.633^{b}$ & $30.805^{\mathrm{c}}$ & $488.75^{\mathrm{a}}$ \\
\hline 'Stella' & $18.0^{\mathrm{c}}$ & $0.813^{\mathrm{a}}$ & $22.109^{f}$ & $363.50^{c}$ \\
\hline 'Andreiaş' & $18.7^{b}$ & $0.413^{c}$ & $45.338^{\mathrm{a}}$ & $271.25^{\mathrm{e}}$ \\
\hline 'HC 27/4' & $17.8^{c}$ & $0.755^{\mathrm{b}}$ & $23.509^{\mathrm{e}}$ & $293.50^{\mathrm{e}}$ \\
\hline 'George' & $17.5^{\mathrm{c}}$ & $0.535^{\mathrm{b}}$ & $32.616^{\mathrm{b}}$ & $268.00^{\mathrm{e}}$ \\
\hline 'Ciliegia di Ottobre' & $16.2^{\mathrm{d}}$ & $0.915^{\mathrm{a}}$ & $17.704^{\mathrm{f}}$ & $68.03^{\mathrm{f}}$ \\
\hline 'Fromm' & $17.0^{\mathrm{c}}$ & $0.658^{\mathrm{b}}$ & $25.835^{\mathrm{d}}$ & $266.25^{\mathrm{e}}$ \\
\hline
\end{tabular}

${ }^{1}$ different letters correspond with the significant statistical difference for $\mathrm{P} \leq 5 \%$, Duncan test

* SDS - the soluble dry substance;

** TA - the titratable acidity;

*** SDS : TA - the soluble dry substance and titratable acidity ratio 


\section{CONCLUSIONS}

Using sexed hybridization, five new sweet cherry cultivars have been obtained with traits that are superior to their parental genotypes: good resistance to frost ('George', 'Maria', and 'Andreiaş'), late bloom ('Margonia'), earliness ('Cătălina'), lateness ('George'), high productivity, fruit quality, and resistance to cracking.

\section{Acknowledgments}

This work was partially supported by the Romanian Ministry of Research and Innovation, Programme PNIII P1-1.2-PCCDI-2017-0662 "Increasing the Institutional Capacity of Research-Development-Innovation in the Field of Ecological Fruit Growing".

\section{REFERENCES}

Beceanu D. 2008. Antioxidizing properties of fruits and vegetables. Lucrări Ştiinţifice - Horticultură 51: 923-928.

Branişte N., Budan S., Butac M., Militaru M. 2007. Varieties of trees, fruit bushes and strawberries created in Romania. Paralela 45, Piteşti, 476 p. [in Romanian]

Budan S., Grădinariu G. 2000. The cherry tree. Ion Ionescu de la Brad, Iaşi, 264 p. [in Romanian]

Chaovanalikit A., Wrolstad R.E. 2004. Total anthocyanins and total phenolics of fresh and processed cherries and their antioxidant properties. Journal of Food Science 69(1): 67-72. DOI: 10.1111/j.13652621.2004.tb17858.x.

Cociu V., Oprea Şt. 1989. Research methods of breeding of the fruit tree species. Dacia, Cluj-Napoca, 174 p. [in Romanian]

Crisosto C.H., Crisosto G.M., Ritenour M.A. 2002. Testing the reliability of skin color as an indicator of quality for early season 'Brooks' (Prunus avium L.) cherry. Postharvest Biology and Technology 24: 147-154. DOI: 10.1016/s0925-5214(01)00190-9.

Demirsoy L., Demirsoy H. 2008. Characteristics of the fruit epidermis of some sweet cherry cultivars. Acta Horticulturae 795: 805-810. DOI: 10.17660/actahortic.2008.795.129.
Fleckinger J. 1964. Phénologie et arboriculture fruitière. In: Grisvard P., Chaudun V. (Eds.), Le Bon Jardinier, vol. 1. Encyclopédie Horticole, 152 ed. La Maison Rustique, Paris, pp. 362-372.

Fotirić Akšić M., Nikolić T. 2013. Analysis of pomological traits in new promising sweet cherry genotypes. Genetika 45(3): $\quad 873-880 . \quad$ DOI: 10.2298/gensr1303873a.

Fotirić Akšić M., Rakonjac V., Nikolić D., Zec G. 2013. Reproductive biology traits affecting productivity of sour cherry. Pesquisa Agropecuária Brasileira 48(1): $\quad 33-41 . \quad$ DOI: $10.1590 / \mathrm{s} 0100-$ 204x2013000100005.

Ganopoulos I., Farsakoglou A.M., Aravanopoulos F., Molassiotis A., Michailidis M., Malliarou E. et al. 2018. Towards sweet cherry (Prunus avium L.) breeding: phenotyping evaluation of newly developed hybrids. Euphytica 214; 99; 11 p. DOI: 10.1007/s10681-018-2179-2.

Ghimicescu G. 1977. Chemistry and analysis of food, beverages and spices. Junimea, Iaşi, 314 p. [in Romanian]

Głowacka A., Rozpara E. 2014. Examination of the suitability of different pollinators for four sweet cherry cultivars commonly grown in Poland. Journal of Horticultural Research 22(1): 85-91. DOI: 10.2478/johr-2014-0010.

Hallmann E., Rozpara E. 2017. The estimation of bioactive compounds content in organic and conventional sweet cherry (Prunus avium L.). Journal of Research and Applications in Agricultural Engineering 62(3): 141-145.

Höfer M., Giovannini D. 2017. Phenotypic characterization and evaluation of European cherry collections: A survey to determine the most commonly used descriptors. Journal of Horticultural Science and Research 1(1): 7-12. DOI: 10.36959/745/392.

Jänes H., Ardel P., Kahu K., Kelt K., Kikas A. 2010. Some biological properties and fruit quality parameters of new sweet cherry cultivars and perspective selections. Agronomy Research 8 (Special Issue 3): 583-588.

Jayaprakasha G.K., Singh R.P., Sakariah K.K. 2001. Antioxidant activity of grape seed (Vitis vinifera) extracts on peroxidation models in vitro. Food Chemistry 73: $285-290$. DOI: $10.1016 / \mathrm{s} 0308-$ 8146(00)00298-3. 
Kappel F., Fisher-Fleming B., Hogue E. 1996. Fruit characteristics and sensory attributes of an ideal sweet cherry. HortScience 31(3): 443-446. DOI: 10.21273/hortsci.31.3.443.

Long L.E. 2013. Fruit Bud Hardiness. How the cold affects fruit budsGood Fruit Grower; December 6, 2013. Washington State Fruit Commission. https://www.goodfruit.com/how-the-cold-affectsfruit-buds/

Maglakelidze E., Bobokasvili Z., Kakashvili V., Tsigriasvili L. 2017. Biological and agricultural properties of sweet cherry (Prunus avium L.) cultivars in Georgia. International Journal of Science and Research 6(9): 796-803. DOI: 10.21275/art20176036.

Milatović D. 2011. Breeding and cultivars in cherry. In: Sweet cherry and sour cherry. Naučno voćarsko društvo Srbije. Čačak, Serbia, pp. 119-213. [in Serbian]

Rodrigo J. 2000. Spring frosts in deciduous fruit trees morphological damage and flower hardiness. Scientia Horticulturae 85: 155-173. DOI: 10.1016/s0304-4238(99)00150-8.

Ruisa S. 2008. Fruit quality of sweet cherries grown in Latvia. Acta Horticulturae 795: 883-888. DOI: 10.17660/actahortic.2008.795.143.

Sansavini S., Lugli S. 2008. Sweet cherry breeding programs in Europe and Asia. Acta Horticulturae 795: 41-57. DOI: 10.17660/actahortic.2008.795.1.

Schuster M., Grafe C., Wolfram B., Schmidt H. 2014. Cultivars resulting from cherry breeding in Germany. Erwerbs-Obstbau 56(2): 67-72. DOI: 10.1007/s10341-014-0204-8.
Skrzyński J., Leja M., Gonkiewicz A., Banach P. 2016. Cultivar effect on the sweet cherry antioxidant and some chemical attributes. Folia Horticulturae 28(1): 95-102. DOI: 10.1515/fhort-2016-0011.

Turner J., Seavert C., Colonna A., Long L.E. 2008. Consumer sensory evaluation of sweet cherry cultivars in Oregon, USA. Acta Horticulturae 795: 781-786. DOI: 10.17660/actahortic.2008.795.125.

Quero-García J., Iezzoni A., Puławska J., Lang G. 2017. Cherries: Botany, Production and Uses. CABI, Boston, USA, 550 p. DOI: 10.1079/9781780648378.0000.

UPOV 2006. Sweet cherry. Guidelines for the conduct of tests for distinctness, uniformity and stability. International Union for the Protection of New Varieties of Plants, Geneva, Switzerland, $31 \mathrm{p}$.

Usenik V., Fabčič J., Štampar F. 2008. Sugars, organic acids, phenolic composition and antioxidant activity of sweet cherry (Prunus avium L.). Food Chemistry 107(1): 185-192. DOI: 10.1016/j.foodchem.2007.08.004.

Vangdal E. 1985. Quality criteria for fruit for fresh consumption. Acta Agriculturae Scandinavica 35: 4147. DOI: $10.1080 / 00015128509435757$.

Vursavuş K., Kelebek H., Selli S. 2006. A study on some chemical and physico-mechanic properties of three sweet cherry varieties (Prunus avium L.) in Turkey. Journal of Food Engineering 74(4): 568-575. DOI: 10.1016/j.jfoodeng.2005.03.059.

Webster A.D., Looney N.E. 1996. Cherries: Crop Physiology, Production and Uses. CAB International, Wallingford, UK, 513 p. 